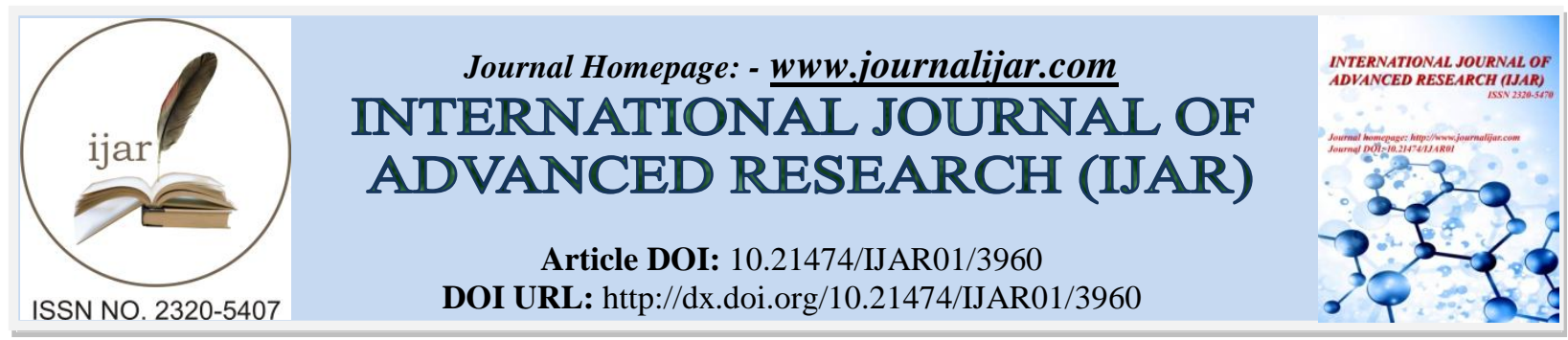

RESEARCH ARTICLE

\title{
MORPHOMETRY AND ITS IMPACT ON LANDUSE IN NANOI RIVER BASIN, ASSAM, USING GEO- INFORMATICS TOOL.
}

\author{
Dr. Niranjan Bhattacharjee \\ Assistant Professor(Sr.), Dept. of Geography, Pandu College, Guwahati University, Assam.
}

\section{Manuscript Info}

Manuscript History

Received: 16 February 2017

Final Accepted: 12 March 2017

Published: April 2017

Key words:-

Morphometry, Channel characteristics,

Flood, Environment, Hydrology,

Morphology,

\section{Abstract}

Morphometric analysis of a river is an essential requirement to evaluate the nature of changes of river basin and its impact on land use pattern. Unstable nature of a river caused unprecedented changes on land and hydrology. A drainage basin being the best unit for hydro-physical studies among many (Horton, 1945, Chorley, 1969), bears a great significance in today's hydro-environmental investigation of channel network and drainage morphology along with flood events and their relationship with land, water and man (Chorley,1969b). Hydrogeomorphic processes play key roles in creating, modifying, or destroying aquatic habitat and act as ecological disturbances. The drainage network, land, water, soil, geology and forest covers are the most effective approach in land use and land cover of a river basin area. Land use is a dynamic phenomenon. Due to increasing population growth and infrastructural activities in India people are using the lands which were earlier not suitable because of impact of the morphometric character of river basin. Geo-informatics tools are being increasingly used in resource evaluation to improve the quality and quantity of the land in a basin area. In the northern plains of Assam the river Nanoi plays a critical role by changing land use pattern and causing long and recurring floods hazard on floodplain. Records revealed that more than 100 years long history of flood problems the river basin continuously suffering through extensive flood (Gait, 1926). The surface water and ground water are the main sources of water which is mainly depending on rainfall for the proper land use pattern in the basin area. The basin gradient of Nanoi river is extremely low in the downstream part and suddenly step in the foothill region of the Arunachal Himalaya. During heavy downpour particularly lower part experienced severe flood and also changed the land use pattern in every year. Therefore, the land use is intimately related to the mechanism of river morphometry in Nanoi river basin. The researcher tried to find out the different factors of river basin area responsible for change the land use using Geo-informatics tools and toposheet of the concerned area. 


\section{Introduction:-}

Land use pattern of late, become too intricate especially in the marginal areas of high hills, because of the area's complex nature caused partly by natural phenomena and increasing riverine dwellers. River basin areas are highly influenced by river morphometry. Therefore, there are urgent needs to investigate the impact of river on change of land use pattern. The process of investigation of land use pattern, role of morphometry and behavior of the river basin may be quite rightly dragged as the morphometric behavior of the basin length space and time get change to exercise. River basins have from the time immemorial been the storehouse a host of resources having their roles on creating landuse differentials in order to improve the scope and prospects of overall sustainable development of human society in the basin. The land use has now become so complex and dynamics and data sources of such an area have become so large, that a simple traditional technique cannot cover up. To yield suitable data and information and bring rational meaning of landuse complexities in the midst of basin morphometric dynamics has led to search for an alternative technique of data acquisition, data processing, data mapping and data analysis using effective geo-informatics tool and techniques. The Nanoi river basin being a Bhutan-Himalayan tributary basin to the Brahmaputra has been found to have complex geomorphometric behavior and pattern having their far reaching impact on land use. Here in this paper an attempt is made to explore some of the basin morphometric behavior and their impact on land use in the basin.

\section{Study Area:-}

The river Nanoi oozes from the Bhutan hill Tangchar, southern part of the Bhutan hill (1220m). The topography along the stream is such that the valley gradients decline steeply as the rivers advance from the hills to the plains of the Brahmaputra valley (Fig.1). From the origin point it flows towards the south and eastern Assam at the 103 no. boundary stone. In the hilly area its takes numbers of small tributaries.

The Nanoi river basin, a part of reverine built-up plain of Brahmaputra valley composed of fine alluvial sediments, which has been washed by sheet flood causing river bank erosion and channel shifting almost every year due to its hydro-geomorphic factors. The hydro-geomorphic characteristic of the river basin has caused serious geomorphic, hydrologic and environmental problem in the southern part of the Darrang district. The total length of the Nanoi river is 104.275 kilometer with the basin area of $959.460 \mathrm{sq} \mathrm{km}$. The basin extending from $26^{0} 15^{\prime} 45.14^{\prime \prime} \mathrm{N}$ to $27^{0}$ $04^{\prime \prime} 57.84^{\prime \prime} \mathrm{N}$ latitude and $91^{\circ} 48^{/ /} 59.66^{\prime \prime} \mathrm{E}$ to $91^{0} 58^{\prime \prime} 42.536^{\prime \prime} \mathrm{E}$ longitude.

The morphometric characteristics play dominants roles to create typical characteristics of environment and landuse pattern of the basin area. The basin area receives an annual mean rainfall of $210 \mathrm{~cm}$. the master stream i.e. is the Nanoi is fed by numbers of sub tributaries which supply water to the basin mainly during summer season.

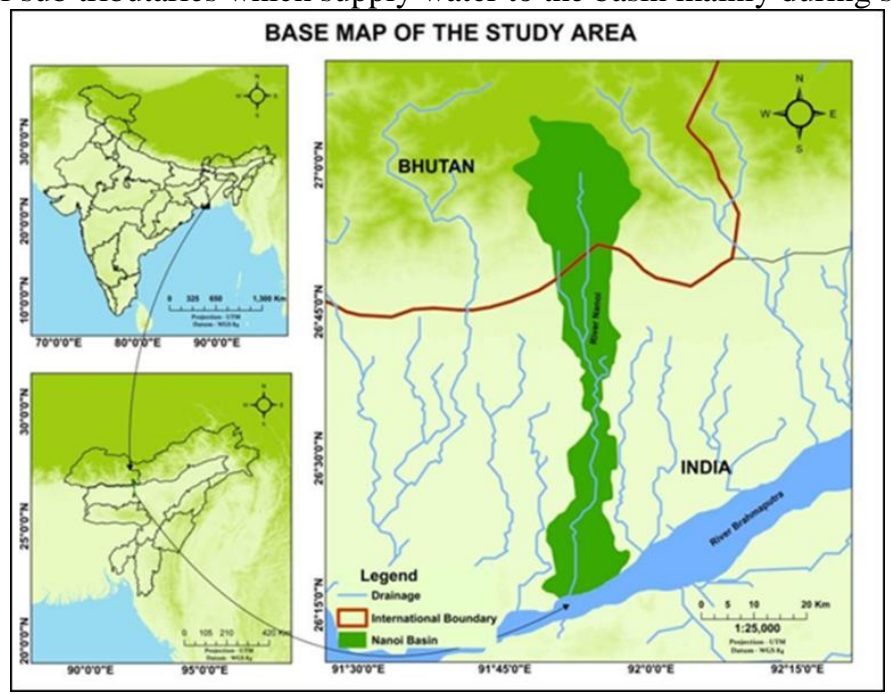

Fig.1:- Location Map of Nanoi River Basin

The river restoration efforts need to be founded on an understanding of characteristics and functional relationships with land use and structure of aquatic habitat, the influence of routing on impact propagation and legacies on current conditions and restoration potential. Geographic variations of climate, physiography (geology and topography), and vegetation impart a strong hydro-morphometric problem to Nanoi river basin. 


\section{Objectives:-}

The main objectives of the study are-

1. to investigate the morphometric characteristics of the Nanoi river

2. to examine the impact of basin morphometry and hydro-geomorphic characteristics on landuse,

\section{Methodology:-}

The methodology has been designed to extract the basin morphometric parameters such as areal and linear aspects of the river basin were determined and computed. The Survey of India (SOI) topographical map (R.F.1:50,000) of 1972 and along with IRS LISS-III image of 2008 are used for the preparation of the basin map of the study area. The stream frequency and drainage networks of the basin are then digitized on the basis of the basin map in order to identify hydrologic and morphometric characteristics and behavior along with areas of river associated problems and its impact on landuse. The objectives of this study were achieved by using GIS, this analysis related to various parameter of river basin. Prepared maps and diagrams are then used to analyse and find the impact of hydrogeomorphic pattern on landuse in the basin area by using GIS software like ArcInfo and Erdas.

\section{Basin Morphometry:-}

Morphometry analysis of the river is an essential requirement to evaluate the impact on landuse pattern. Morphometry means measurement and mathematical analysis of the configuration of the earth surface, shape and dimension of its landforms (Clarke,1966) which can be well extended in case of a drainage basin to cover up its linear, areal, relief aspects and slope contribution(Nag and Chakrabarty,2003). The Nanoi river basin situated in the middle of the high hills and the grand river Brahmaputra in the south and the adjacent riverine plains in the east and west. The basin characterized by south sloping hilly terrain in its upper part, the swelling plains in the upper middle part and flat plains on the lower middle and lower parts of the basin (Fig. 2).

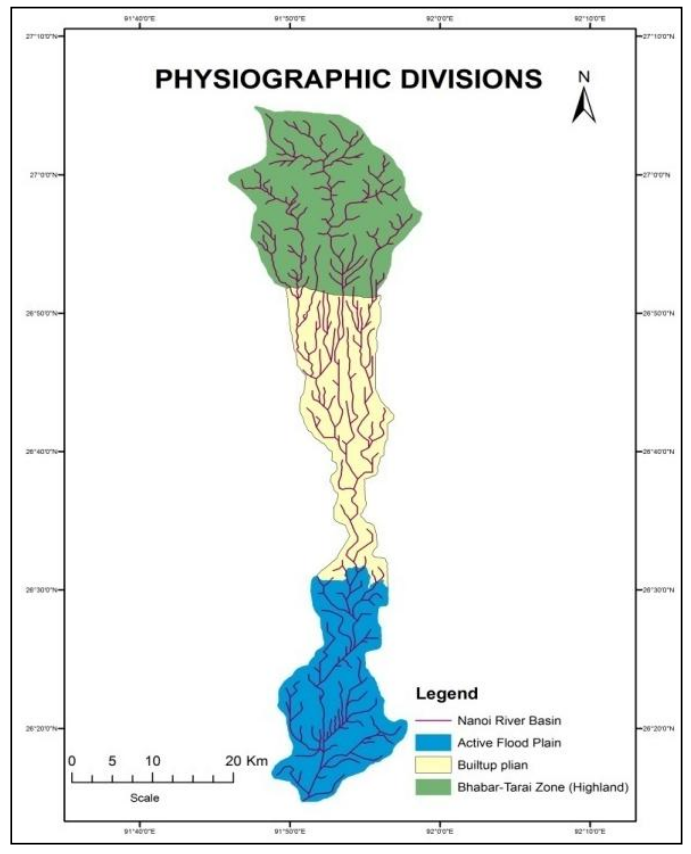

Fig. 2:- Physiographic Divisions.

Morphometry is the measurement and mathematical analysis of the configuration of the earth surface, shape and dimension of its landforms (Clarke,1966) which can be well extended in case of a drainage basin to cover up its linear, areal, relief aspects and slope contribution(Nag and Chakrabarty,2003). The Nanoi river basin in the midst of the high hills and the mighty river Brahmaputra in the south and the contiguous riverine plains in the east and west being characterized by south sloping hilly terrain in its upper part, the undulating plains in the upper middle part and flat plains on the lower middle and lower parts of the basin has been expressing a significantly distinguishable local set-up. The geological basement of this fluvio-geomorphic peculiarity of the basin is such that in the Arunachal Himalayan part of the basin it is composed of tertiary sediments. The foothills are composed of boulders, gravels, 
pebbles, cobles, grit and sand, while the plain part is composed of thick layers of river born alluvial deposits. A number of factors right from geologic basement through topographic to fluvio-geomorphic ones have been found to be responsible for such a characteristic landform set-up. The geological basement of this fluvio-geomorphic peculiarity of the basin is such that in the Arunachal Himalayan part of the basin it is composed of tertiary sediments. The foothills are composed of boulders, gravels, pebbles, cobles, grit and sand, while the plain part is composed of thick layers of river born alluvial deposits.

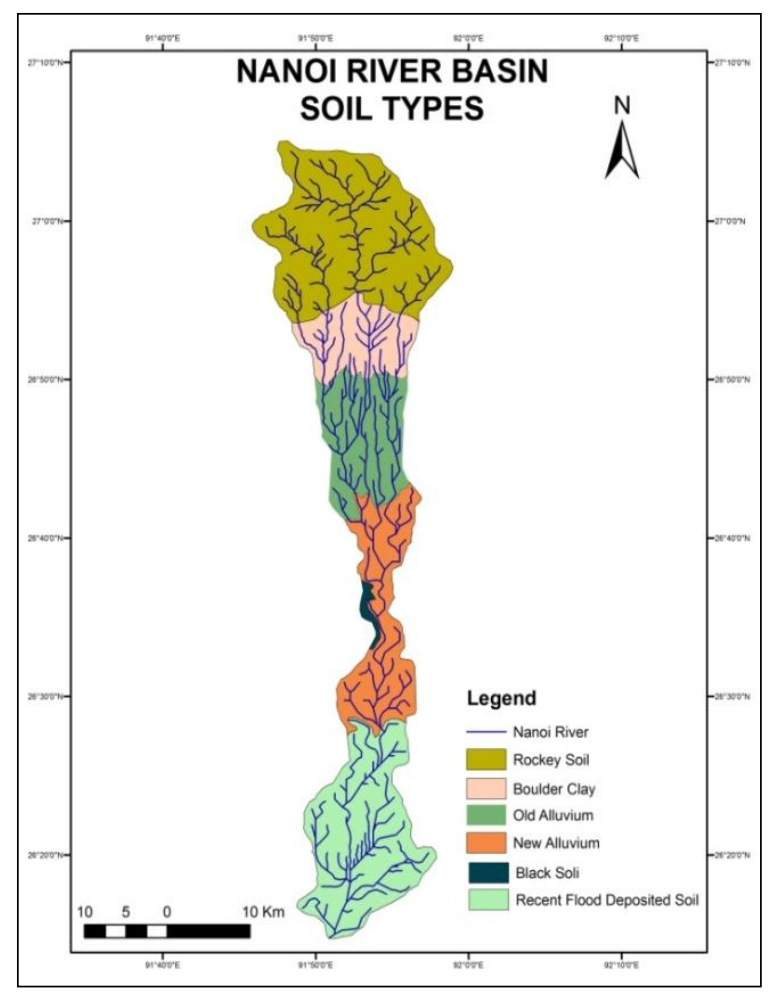

Fig. 3:- Soil Types.

Slope analysis implies that the basin having the equal areas within slope groups of equal interval which is not uniform. It is found that below the $8^{0}$ slopes the basin covers 68.29 percentage of the total areas while $8^{0}$ to $23^{0}$ has the percentage share of 16.12 . Beyond $23^{0}$ slope up to about $77^{0}$ the basin covering as large as 25.59 percent of basin area. Such a state of slope pattern of the basin clearly indicates that there is hurriedly changing slope distribution as one goes from mountainous areas to the Nanoi river mouth in the neighborhood of the Brahmaputra. As figure has shown that the height increases the area share decreases abruptly. Such a state of relief change can well be substantiated by the river or basin profile having abrupt fall with inflexion in the foothill areas and perceptibly very less relief, specially the relative relief in the built-up and floodplain areas down the foothills. 


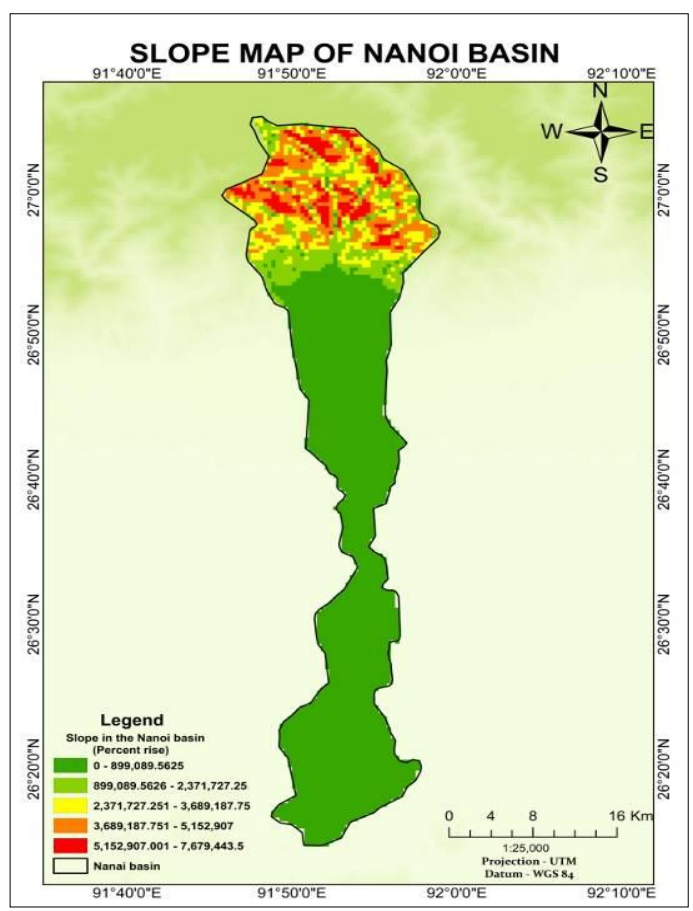

Fig.4:-Slope Map

Table.1:- Showing Channel and Basin gradient of the Nanoi river in different sites.

\begin{tabular}{|l|l|l|l|l|l|}
\hline River & $\begin{array}{l}\text { Total } \\
\text { length }\end{array}$ & $\begin{array}{l}\text { Segment } \\
\text { length(in } \\
\text { km. }\end{array}$ & $\begin{array}{l}\text { Maximum channel } \\
\text { relief }\end{array}$ & $\begin{array}{l}\text { Channel gradient } \\
(\mathrm{m} / \mathrm{km}) \text { of the segment }\end{array}$ & Site \\
\hline \multirow{2}{*}{ Nanoi } & \multirow{2}{*}{$104.27 \mathrm{~km}$} & 26.21 & $1310.64 \mathrm{~m}$ & 50.005 & Foot hill \\
\cline { 3 - 6 } & 44.04 & $120 \mathrm{~m}$ & 2.725 & Built-up plain \\
\cline { 3 - 6 } & 34.025 & $60 \mathrm{~m}$ & 1.763 & Active flood Plain \\
\cline { 2 - 5 } & & $\mathbf{1 0 4 . 2 7 5}$ & $\mathbf{1 3 1 0 . 6 4} \mathbf{~ m}$ & $\mathbf{1 2 . 5 6 9}$ & Entire channel \\
\hline
\end{tabular}

The region is steeply downward towards the southern part. In the upstream the topography of the channel is steeply raising which create a new type of valley dimensions. So the stream is such that the valley gradients decline steeply as the stream flowing from the hill to the plains of Brahmaputra valley. After traveling through a length of about 50 kilometer from the hills their course becomes smooth, only $1.76 \mathrm{~m} / \mathrm{km}$ (Table.1).

The Nanoi river basin bounded by the Bhutan Himalaya in the north and the Brahmaputra in the south has almost an elongated shape covering about $2 / 3^{\text {rd }}$ of the areas of the basin above the middle part of the basin, while about $1 / 3^{\text {rd }}$ lies in the lower part of the basin. The form ratio mainly concerned with the length and area. The basin form ratio is 0.088 substantiates that basin is an elongated one. It implies that the basin is mostly controlled by the structure. Shape ratio is the ratio between the basin length and basin area where in Nanoi river the ratio 9.08 indicates the sinuous shape and it implies the hard structure of the basin (table.2).

Table.2:- Arial aspect of Nanoi river basin

\begin{tabular}{|l|l|l|l|l|l|}
\hline Basin area & Basin length & $\begin{array}{l}\text { Form Ratio } \\
(\mathrm{F})\end{array}$ & Shape ratio $(\mathrm{S})$ & $\begin{array}{l}\text { Lemniscates } \\
\text { Ratio }(\mathrm{k})\end{array}$ & $\begin{array}{l}\text { Sinuosity } \\
\text { index SI }\end{array}$ \\
\hline $959.46 \mathrm{~km}^{2}$ & $104.27 \mathrm{~km}$ & 0.0882 & 9.088 & 2.272 & 1.116 \\
\hline
\end{tabular}

The basin has average stream frequency in the tune of 0.04 numbers per sq.km. however in the hilly areas including the foothill one the stream frequency ranges from 0.15 to 0.001 per sq $\mathrm{km}$., subsequently the drainage density in the basin $\left(0.62 \mathrm{~km} / \mathrm{km}^{2}\right)$ like other basin of the Brahmaputra valley or elsewhere has a good positive relation. 
Table.3:- Linear aspect of Nanoi river basin.

\begin{tabular}{|c|c|c|c|c|c|c|}
\hline $\begin{array}{l}\text { Order of } \\
\text { streams }\end{array}$ & $\begin{array}{l}\text { Number of } \\
\text { streams } \\
\mathrm{Nu}\end{array}$ & $\begin{array}{l}\text { Bi Ratio } \\
\mathrm{Rb}\end{array}$ & $\begin{array}{ll}\text { Length } & \text { of } \\
\text { Streams } & \\
\text { Lu } & \end{array}$ & $\begin{array}{l}\text { Stream } \\
\text { Frequency } \\
\text { (Fs) }\end{array}$ & $\begin{array}{l}\text { Drainage } \\
\text { Density(Dd) } \\
\mathrm{km} / \mathrm{km}^{2}\end{array}$ & $\begin{array}{l}\text { Length } \\
\text { ratio } \\
\mathrm{L}_{\mathrm{R}}\end{array}$ \\
\hline $1^{\text {st }}$ Order & 143 & - & 316.13 & 0.15 & \multirow[t]{5}{*}{0.62} & 0.31 \\
\hline $2^{\text {nd }}$ Order & 38 & 3.76 & 100.47 & 0.04 & & 0.66 \\
\hline $3^{\text {rd }}$ Order & 3 & 12.66 & 66.88 & 0.003 & & 0.84 \\
\hline $4^{\text {th }}$ Order & 2 & 1.05 & 56.73 & 0.002 & & 1.02 \\
\hline \multirow[t]{2}{*}{$5^{\text {th }}$ Order } & 1 & 2.00 & 58.28 & 0.001 & & - \\
\hline & & $\begin{array}{l}\text { Mean } \mathrm{Rb} \\
4.86\end{array}$ & & & & $\begin{array}{l}\text { Mean } L_{R-} \\
0.71\end{array}$ \\
\hline
\end{tabular}

Bifurcation ratio of the $4^{\text {th }}$ order Nanoi basin is 2.00 , there are observable deviations from the average 4.86 among the bifurcation ratios of successive pairs of stream orders. The widely varying bifurcation ratios with the increasing orders of streams specially in case of lower reaches of the basin reveals the frequently recurring flash floods as well as the strong hydraulic action as compared that in the topographically controlled up stream areas. Elongated basin have low $\mathrm{Rb}$ value, where circular basin have high $\mathrm{Rb}$ value (Morisawa, 1985). The streams in the basin have been marked by differential length as per topographic, hydrologic, and hydraulic control (Horton, 1945). The length of the stream ranges length of the different orders of streams ranges shown in table. 3 where in length ratios varies from 0.31 to 1.02 with an average of 0.71 .

\section{Hydrologic Determinants:-}

The drainage basin restrain a common network pattern in all the geomorphic units except the hills top area as there are only 143 first order streams, 38 second order streams, 3 third, 2 fourth order and 1 fifth order streams drained to the master stream Brahmaputra totaling altogether to 187 streams identified by using Strahler's technique of stream ordering (Strahler, 1952). The density and frequency in the drainage basin are having slight differences among the various physiographic units. The Nanoi River of the area creates flood of high intensity and serious devastation. During winter months of November December and January the water level goes down to that of base flow. For example during winter months of 1987 the water levels goes down to the extent of 49 meter but during rainy season the water level went up to the 54.01meter where the danger level is 52.74 meter. This happened during August to September. Discharge during winter season was of the under of base flow measured at 1.02 cumecs, which rise to 239.10 cumecs during the summer season's.

Table.4:- Hydrological Characteristics of Nanoi River.

\begin{tabular}{|c|l|l|l|l|l|l|}
\hline $\begin{array}{l}\text { Rivers at } \\
\text { NH 52 site }\end{array}$ & $\begin{array}{l}\text { Avg. maximum } \\
\text { water level and } \\
\text { discharge } \\
\text { (yearly) }\end{array}$ & $\begin{array}{l}\text { Avg. minimum } \\
\text { water level and } \\
\text { discharge } \\
\text { (yearly) }\end{array}$ & $\begin{array}{l}\text { St.dev. } \\
\text { maximum } \\
\text { water level } \\
\text { and } \\
\text { discharge }\end{array}$ & $\begin{array}{l}\text { St.dev. } \\
\text { minimum } \\
\text { water level } \\
\text { and } \\
\text { discharge }\end{array}$ & $\begin{array}{l}\text { CV of } \\
\text { maximum } \\
\text { water level } \\
\text { and } \\
\text { discharge }\end{array}$ & $\begin{array}{l}\text { CV of } \\
\text { maximum } \\
\text { water level } \\
\text { and } \\
\text { discharge }\end{array}$ \\
\hline $\begin{array}{c}\text { Nanoi } \\
(1988-2008)\end{array}$ & 53.50m & $50.08 \mathrm{~m}$ & 0.60 & 0.042 & 1.13 & 0.84 \\
\cline { 2 - 7 }
\end{tabular}

This also bear out that the Nanoi river is always in high spate of flood and consequent problems associated with loss of crop, cropland, human habitation, fertile soil along with shifting of river channel. It is found that the river remains with almost dry bed during the rainless period and with high spate of water levels beyond the river's carrying capacity during the period of heavy rainfall.

\section{Hydro-morphometric Impact on Landuse:-}

The steeply rising hill morphometry in the areas of elevation ranging from 60 meter to 1310.64 meter with rugged relief and high slope ranging from 8 to 79 degree in the northern part of the basin give mainly the forest cover of rich but because of growing human interference now it is degraded. Though the drainage density is $0.62 \mathrm{~km}$ per square $\mathrm{km}$, drainage frequency more than 1 nos per square $\mathrm{km}$ the basin suffer severe soil and bank erosion problem in the upper part due to human encroachment. It is observed that the differential relief and slope characteristics stream network and distribution pattern have their exercising role on the distributional pattern of land use. The 
abruptly hill morphometry in the areas of elevation in the northern part of the basin give mainly the forest cover of rich and degraded. The medium drainage densities 0.62 per square $\mathrm{km}$ and the low drainage frequency have all rendered awful condition for luxuriant growth of forest cover. In spite of congenial natural growth condition for forest growth the area has under gone human aggression as a result of which there have changes in the quality and quantity of forest. Even as the agriculture main stay of the majority of the population in the Brahmaputra, the figures indicates the share of agricultural land in the basin is low in the tune of around 20 percent. It has experience that the Nanoi basin is a highly flood prone basin and the land in the basin is not suitable as expected for some other basins characterize by less flood impact, less forest cover and less amount of wasteland and wetlands and less amount of grassland areas.

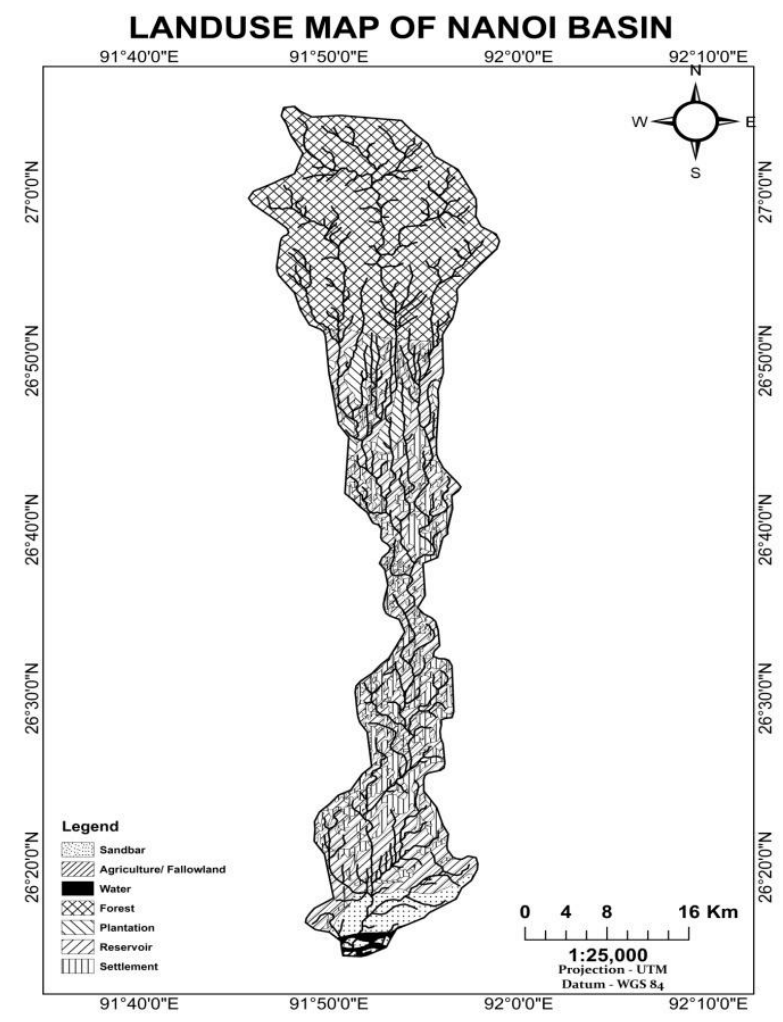

Fig.4:- Landuse map Based on Satellite Image,2008

Very low relief in the plain (absolute relief ranging from 60 to 250 meter) and low slope, low drainage density, low drainage frequency and reticulated pattern of drainage network have developed a condition for uncertainty in the sound growth and production of agricultural crops. Hence it is observe the strong impact of topographic or geomorphologic impact in the basin. The grasslands are of riverine origin mostly scattered along the river Nanoi and its major tributaries in basin middle and lower parts. Definitely such a pattern of land cover indicates the impact of topographic morphometry and river created soil composition on the share of grassland in the basin. The existence of tea gardens needs elevated of old alluvium which plays a major role in the Nanoi basin also. As the basin is mostly flat one having a network of drainage lines wastelands and wetlands are having their significant impact on their distribution.

\section{Result and Conclusion:-}

The Nanoi basin is a really a very complex in morphometric, hydrologic and land use and land cover pattern. Actually this basin lies almost unexplored in these areas of spatial pattern of natural and cultural development. The overall morphometric characters of the drainage basin shows the dendraitic to semi dendraitic pattern of the river with moderate texture. The bifurcation ratio in the basin indicates usual basin category, low drainage density shows it has highly permeable soil and coarse texture. The value of form and shape ratio indicates the basin is elongated, whereas the basin associated with moderate to high relief and flat ground slope. 
River systems are dynamic. Restoration projects that do not acknowledge and plan for expected variability in habitat-forming processes associated with the hydrologic, geomorphic, and vegetation regimes are unlikely to be successful in the long term. In the study areas enhancement of morphological problems and spatio-temporal changes has also been noticed. The changing pattern of hydrological components of the river, augmentation and controlling of flood and its associated problems in the lower catchment area are mainly caused due to the hydro-geomorphic nature of the river basin. The basin being fed with a number of big and small streams carrying much water including the flood waters creates flood and erosion havocs differentially at different locations. Thus the study shows that GIS techniques have efficient tools to understand terrain parameters and drainage pattern which helps to manage the river associated problems in situ. Unless the multifaceted behaviors of landforms, landscape, and the pattern of human habitation and activities, and the human need as well are investigated properly the real fact of flood and its associated problems could never be understood. The present study is to observe some of basin morphometry and its impact on land use. The basin needs further more investigation to examine the cause-effect relationship to cover up more scope of operation towards identification, understanding, evaluation, decision making and management of the basin parameters and resources.

\section{References:-}

\begin{tabular}{|l|l|}
\hline Clarke. JI, (1966) : & $\begin{array}{l}\text { Morphometry from Maps, Essays in Geomorphology, Elsevier Publ. } \\
\text { Co.,NewYork pp.234-274 }\end{array}$ \\
\hline Chorley, R.J., (1969): & $\begin{array}{l}\text { "The Drainage Basin as the Fundamental Geomorphic Unit" in Chorley, } \\
\text { R.J.(edit), Introduction to Fluvial Process Mathuen and Co. Ltd. London, 69-87. }\end{array}$ \\
\hline Gait, E.,(1926): & A History of Assam, Lawyers Book Stall, Guwahati. (Rep. 1984), Pp.42-43. \\
\hline Horton, R.E., (1945): & $\begin{array}{l}\text { 'Erosional Development of Streams and their Drainage Basin-Hydro physical } \\
\text { Approach to Quantitative Morphology",Geographical Society of America, } \\
\text { Bulletin, Vol.56, No. 3, PP.275-370 }\end{array}$ \\
\hline Morisawa, M. (1985): & $\begin{array}{l}\text { "Geomorphology text books: rivers forms and process, Chapter,5”Structural and } \\
\text { lithological control"pp.24 }\end{array}$ \\
\hline $\begin{array}{l}\text { Nag. SK. and Chakraborty. } \\
\text { S.(2003): }\end{array}$ & $\begin{array}{l}\text { Influences of rock types and structures in the development of drainage net work } \\
\text { in hard rock area, J. Indian soc remote sensing. PP.45-49 }\end{array}$ \\
\hline Strahler, A.N.,(1952): & $\begin{array}{l}\text { "Dynamic Basis of Geomorphology"Bulletin. Geological Society of America, } \\
\text { No. 63, PP 923-38 }\end{array}$ \\
\hline
\end{tabular}

